\title{
Guidelines for Solving Bullying Behaviors among Islamic Private School Students in Songkhla Province
}

\author{
Kasetchai Laeheem ${ }^{1}$ \\ ${ }^{1}$ Faculty of Liberal Arts, Prince of Songkla University, Hatyai, Thailand \\ Correspondence: Kasetchai Laeheem, Faculty of Liberal Arts, Prince of Songkla University, Hatyai, Songkhla \\ 90110, Thailand. E-mail: Lkasetchai@yahoo.com
}

Received: April 24, $2013 \quad$ Accepted: June 20, $2013 \quad$ Online Published: August 30, 2013
doi:10.5539/ass.v9n11p83
URL: http://dx.doi.org/10.5539/ass.v9n11p83

\begin{abstract}
The purpose of this research was: to investigate ways to solve problems of bullying behaviors among students of Islamic private schools in Songkhla Province. The data of this qualitative study were collected from brainstorming meetings and critique meetings with representatives of 10 teachers, 10 students, and 10 parents and guardians. The data were analyzed using comparative logic of concepts, theories, research reports, and context based on grounded theory method.

The results of the study revealed that ways to solve problems of bullying behaviors among students of Islamic private schools in Songkhla Province were: group study activities emphasizing training on correct Islamic ways, giving advice, instructive reprimands, providing good models, and teaching religion, discipline training, and organizing special projects emphasizing the socialization process of their mind, emotion, intelligence, and Islamic religious spirit.
\end{abstract}

Keywords: guideline, solve problems, students, bullying behavior, Islamic private schools

\section{Introduction}

Bullying behaviors among students are normal problems happening in schools and are known very well among students themselves, parents, guardians, teachers and educational personnel. This remains a worrying problem that affects students who bully others and students who are bullied. Students who are bullied by other students are usually injured, suffered and don't want to go to school. The bullying remains in their memories until they are adult while students who bully others repeatedly so often that it has become a habit may grow up to be impolite, aggressive, savage, delinquent adults and may eventually become criminals (Farrington, 1993) as can be seen in news about quarrels, youths gathering to fight each other. Usually students who bully others are groups or gangs of students who are physically bigger and stronger than students that they bully; bullied students are usually psychologically and physically weaker or impaired, and bullying is done to hurt them emotionally and psychologically. Even though bullying in schools is prevalent and seriously affect students, society usually over looks and takes it as normal behavior or over teasing or innocent playing for fun among children, and therefore, pays no attention to seriously solving the problem (Laeheem, Kuning, McNeil, \& Besag, 2008).

Bullying is behavior of misbehaved children beginning from unfairly controlling others physically, mentally, emotionally, and in terms of feeling. This behavior hurts others physically and psychologically making others frightened, suffered, and injured. It is an improper behavior of people who have more power and use the power to force or press others who have less power. This incident usually happens to the same students continually and consistently (Marano, 1995; Coloroso, 2004). For this behavior, it is an emotional use of physical strength to threaten others. It is a doing with an intention to hurt others who do not want it to happen to them and who are unhappy about it (Baron, 1996; Astor, Meyer, Benbenishty, Marachi, \& Rosemond, 2005).

Bullying behavior among students in schools has been a problem that has not been completely solved by related personnel and organizations as there have still been reports about aggressive behavior among students in Islamic private schools. It was reported that 22.3 percent of Thai Muslim youth in the three southern border provinces had aggressive behavior (Laeheem \& Baka, 2011); and 20.7 percent had violent behavior (Laeheem \& Baka, 2009). Some youth have violent behavior because they were insulted and thus want to take revenge and use three-inch thick rods as their weapons and the other party were severely injured and were hospitalized while the 
other party escaped to Malaysia (Laeheem \& Baka, 2012). Twenty three percent of students in Pattani Province had bullying behaviors and more students in private schools than public schools were bullies, 34.3 and 32.4 percent, respectively. Thirty five percent of students throw things at others, followed by the highest three behaviors: 24.9 percent kick others; 23.4 percent hit others with their fists; and 12.2 percent slap others (Laeheem, Kuning, \& McNeil, 2008); and students of Islamic private schools in Songkhla Province have bullying behaviors at a moderate level (Laeheem \& Sungkharat, 2012a).

The above data indicate that bullying behavior among students of Islamic private religious schools is at a worrying level and all related personnel and organizations must give importance, pay attention, and give special care to solving the problem of bullying among students in order to provide help and improve their behavior, and to prevent more violent behavior.

The researcher, therefore, was interested in investigating ways to solve bullying behaviors among students in Islamic private schools in Songkhla Province. The study investigated ways that would be suitable for solving the problem of bullying behavior among students in Islamic private schools in Songkhla Province. The results of this study would be useful for all related parties in preventing and reducing bullying behaviors among students before the problem becomes more violent and difficult to prevent, solve, and help each other to solve the problem in time.

\section{Methods}

\subsection{Key Informants and Data Collection Methods}

The data collection methods for this quality study were: brainstorming meetings to jointly set the guidelines for solving the problem of bullying behaviors among students, and critique meetings to jointly consider guidelines for solving the problem in order to make them complete, concrete, and can be put to good use. The data were collected from three groups of key informants: 10 teacher representatives, 10 student representatives, and 10 parent and guardian representatives. In selecting key informants for the brainstorming and critique meetings, the researcher coordinated with the target schools participating in the project from the first year to the second year in order to select participants for the brainstorming meetings and critique meetings.

\subsection{Data Analysis}

The data were analyzed in terms of content based on comparative logic of concepts, theories, research reports, and context according to the grounded theory method with the following steps:

1) Open coding the data collected from the knowledge exchange stage, brainstorming meetings, and critique meetings to open as many codes as possible. The data were coded sentence by sentence or paragraph by paragraph. The coding was divided into two levels: coding the data collected from statements, arguments, supportive statements and exchanged statements. The data were broken or grouped according to their content and topics made by key informants. The data were also coded according to theoretical indicators where knowledge from related documents, concepts, and theories were connected to the content and topics obtained from key informants.

2) Categorizing the data to group them according to their similar codes or their shared attributes whether in context, conditions, or consequences. The data were analyzed based on the clear process of phenomena, data, content, and topics obtained from key informants.

3) Axial coding was performed to analyze the relationships between the categories and context to get the categories and sub-categories as well as the central concept.

\section{Results and Discussion}

From the brainstorming meetings and critique meetings to find ways in solving the problem of bullying behaviors among students in Islamic private religious schools in Songkhla Province, it was found that Islamic principles and concepts must be applied, especially with emphasis on group study activities called "Hallakah" which is detailed as follows:

\subsection{Characteristics and Objectives of Group Study Activities}

Group study activities or "Hallakah" are activities in which participants sit in a circle or a ring with definite and clear objectives and in which the Islamic body of knowledge is integrated with the present body of language. Participants of the group activity designate the content of the discussion. In this case, the issue to investigate is to find guidelines for solving bullying behaviors, therefore, the body of knowledge about bullying behaviors, hurting each other physically and psychologically in Islamic perspective from the Al-Quran, the Al-Haldith, the biography of the Prophet and Islamic ethics are discussed and integrated with the body of knowledge in general. 
This is to provide opportunities to people who have the same purpose of solving the bullying problem to get together and exchange their experience and the content that they have prepared. As a result, they have interrelationships and acquire self-learning, change their attitude and can use the experience they get from the group activity to develop and change their behavior. This corresponds with Amarin (2000), Chatsupakul (2003), and Lhamlert (2009) who state that organizing group activities is organizing activities and experiences for exchange among group members and together they solve the problem so that they have self-learning by analyzing behaviors of members and group activity participants and apply them for their own self-development. Chaipan (2006) specifies that group activities are techniques and methods in which individuals gather to study experiences of different parties in the group, learn their behaviors in being leaders and being group members, their thoughts, to practice interrelations among people, and to learn from experiences by participating in the learning experience activities that are organized for them. Ritnetikul (2009) says that group activities are a process taking place by two or more people who have the same objectives to make a plan to do an activity together, to have interactions using various techniques to help them efficiently achieve the objectives they have set together by analyzing members' behaviors which enables members to acquire self-learning and self-development at the same time as learning about every member of the group. According to Abu Ibanah (n. d.) and Al-bulyan (n. d.), Hallakah is a group activity where group members sit in a circle to study Islam together. For example, to study the Al-Quran and the meaning of education about the Al-Haldith, the biography of the Prophet, Islamic manners, and Islamic religious principles, etc. In addition, other topics can also be formed in order for group members to exchange their knowledge and understanding of current situations so as to develop their potentiality in specific aspects. There are compromises in topics that are different and cooperation in topics that are the same at the same time as providing justice for all parties that have different opinions in order to prevent disharmony that may happen about sub-topics.

Furthermore, the group study activity is a process that provides opportunities for people who have similar problems to get together to help each other think, plan, and solve the problems. They have group activity leaders who are usually religious teachers or general teachers or senior students. The leaders manage group activities so that they achieve the goals that have been set which is for group activity participants to be aware and to understand disadvantages and bad effects of bullying behaviors according to Islamic principles as well as general viewpoints so that they eventually behave well and no longer bully other people. This corresponds to the statement that says a group activity is a process that provides opportunity to everyone to join each other to form a group to solve problems or to do an activity with certain objectives, and the group has a leader who provides detailed information to group members to discuss and exchange information and experiences among themselves (Kemp, 1965; Ohlsen, 1970; Birnbaum \& Wayne, 2000). It is an activity that members can learn and understand each other about how to solve the problems in order for members to develop themselves, to have self-awareness, and to encourage members to cooperate in improving their behavior so that they can live happily in the society (Pumpong, 2003).

The main objectives of group study activities are: to build knowledge and understanding, instill awareness, socialize participants, and to change participants' behaviors from undesirable to desirable behaviors as expected and set in the goals of the activities, and to promote development of social skills and relationships with others. Traxler and North (1966) state that the purposes of group study activities are to familiarize people with the environments in order to provide them with new experiences so that they can develop their potential and efficacy in adapting and treating themselves and keeping prosperity of individuals and the group. According to Button (1974), group study activities are operations with the objectives of helping humans to grow and develop their social skills and relationships with others; to provide opportunities for humans to learn to relate with other people in an atmosphere where they mutually complement each other. Bennett (1963) specifies that group study activities also aim to provide opportunities for group members to achieve treatment, release their emotional stress, have understanding and thinking from other people's problems.

Group study activities are also with the objectives to enable participants to understand themselves and know themselves better. For example, they can learn about their abilities and pitfalls because the group would have reactions that show some facts about them. Group study activities also enable group members to understand others as people know more about others when they do activities together which can lead them to working together better at the same time as adapting their behaviors, personality, and developing their human relationship skills. Chatsupakul (2003) states that the main objectives of group study activities are for humans to better understand the natures of themselves and others in the group which will enable them to adapt themselves to get along with others in the group as they know themselves better, especially their weak points or the kind of people they are when comparing with others in the group. This will also enable them to understand others in the group 
when doing group activities, learning about each other, knowing weak points of themselves and others, and practicing their feeling in terms of ethics and moral while doing group activities. Abu Ibanah (n. d.) and Al-bulyan (n. d.) specify that group study activities aim for members to study together and to socialize people's own mind so as to know how to solve problems as set in the goal of the activity at the same time as to socialize and build the body of knowledge related to Islam in terms of change and invitation.

\subsection{Group Size, Length of Time and Number of Times for Group Study Activities}

In doing group study activities, a suitable group size is determined to obtain efficiency and to meet the objectives of the activity. From a brainstorming meeting, it was agreed that the group should not have more than ten members and the length of time should not exceed one hour and the group activities should be performed for at least 15 weeks to be able to efficiently reduce bullying behaviors among students. Shaw (1971) suggests that in doing group activities, there should not be more than ten group members but if more people are interested in joining, the group should be split into more groups of not exceeding ten people. It is also important to consider the components of the group in terms of relationships and cooperation among members because if there is a problem about relationships of group members and their cooperation, the opportunities to achieve the goals will be lowered. Deighton (1971) suggests that the size of the group should be 10-15 members due to an economic reason, especially the operational expenses. If there are more groups, the expenses will increase. However, if the group has too many members, the opportunities for members to participate will also be reduced and may easily cause disharmony. Chatsupakul (2003) gives importance to the natures of interactions among members as the group size can affect the interrelationship process between different groups. Moreover, in a group with too many members, there may be overlapping or duplicating pieces of work for members to do, and some members may expect to be responsible for all work while others may be frustrated with no work to do and no chance to use their skills. Therefore, the number of group members should not be over 15 and should not be under 10 . However, the suitable group size depends on the situation, objectives, sources of help, and maturity of group members. Ritnetikul (2009) states that to have efficient group study activities with good quality, the group should be small and with members of less than 15 people, especially the group that needs behavior change because every member of the group must have close relationships so that they can freely express their opinions and feeling.

Regarding the length of time and number of times that group study activities should be performed, some academicians suggest that group activities should be performed twice a week but if time for participation is limited, group activities can be organized three times a week (Patterson, 2000). The length of time for doing group study activities depends on the goals and natures of group members. If activities are held in an educational institution, it is necessary to take class time into consideration (Chatsupakul, 2003). For the number of times that group members should participate, it depends on the goals of the group but they should participate in the group activities at least 8 times; however, the more the better (Trotzer, 1977). As for the length of time for participation in a group study activity, class timetable of the educational institution and the ages of group members should be taken into consideration and group members should participate at least 8 times and the group activities should be held twice a week (Lhamlert, 2009). However, according to Ritnetikul (2009), group study activities should be held 2-3 times a week and each time the activity should last 50 minutes depending on how much time there is. Beside this, objectives and natures of the group should also be taken into consideration. For example, for primary school students, the length of time for the group study activity should not exceed one hour because if it is longer, children may become bored and uninterested in the activity. Wattanapong (2005) says that group study activities should be organized twice a week and participation should be at least eight times, and in his study, the activity was organized once a day every day for 16 days, and each time the activity lasted 60 minutes (Wattanapong, 2005). The length of time for a group study activity depends on the objectives of the activity. Thus, the length of time of the group study activity could vary from one to six hours and the average number of times for the activity in his study was 4.7 or it could be $2-3$ times for a short period of time depending on the suitability of the circumstance and the group objectives (Khemmanee, 2002). In addition to taking into consideration the objectives of the group study activity, the basic components of group members such as age, experience, educational level, etc. should also be included. The suitable length of time for the activity should be 50 minutes and the frequency should be twice a week (Sririchan, 2010).

\section{Conclusions and Recommendations}

The group study activity is a process in which a group of people join hands in planning to do an activity together with interrelations and using different techniques to help them efficiently achieve the objectives they have set. Members' behaviors are analyzed which enabled members to have self-learning and self-development. It is also a process that gathers groups of members that is a technique and method to provide opportunities to members to 
participate and exchange their learning experiences and to understand each other's feeling, thinking, behaviors, attitudes, and values, and then reflect the problems and try to find ways of solving them according to the goals that they have set together. This is for members to recognize themselves, have self-awareness and self-development. Members are encouraged to cooperate and improve themselves in order to solve their behavior problems and conflicts, develop their mind so that they can live happily in society. According to Islamic principles, the group study activity refers to a process where members sit in a circle to study together about Islam and about the present world with the objectives to understand, to remind, and to change behaviors of members using religious principles as the main process in socializing members of a Hallakah. Mostly, socialization is conducted through a system of giving knowledge and understanding of Islamic principles. It is a process of training and nurturing the mind, wisdom, body and soul, socializing the mind, transferring knowledge of religion and knowledge of the world, and training about moral, ethics, and disciplines.

The main objectives of group study are for people who assemble themselves to have opportunities to study and learn different skills, work with others and have relationships with others by learning about themselves, improving understanding about themselves, reflecting all aspects about themselves, and trying to understand others so that they can accept others' behaviors. Group study activities provide opportunities for group members to learn each others' natures to enhance good characteristics of members so as to enable them to have skills in working with others, group working, and constructive analysis, solving problems, improving personality, and improving their behaviors. In doing group study activities, the group size, the length of time, the number of times need to be determined properly in order to achieve the objectives that have been set. Relationships among members, cooperation in working together, equal opportunities for members to express their opinions, the objectives of the group study activity, ages of group members, their experience, their educational level, and the suitability of the circumstance also need to be considered. The group size should be with 5-15 members; the length of time should be 30-60 minutes for each time; the frequency of the activity is 2-3 times a week; and the whole period of time for group study activity operation should not exceed two months.

Doing group study activities is of great benefits for members who participate in the activities and to related personnel and organizations. For members, they learn about themselves and have self-awareness, self-realization and realization about others, have self-motivation, understanding themselves and others, ability to make decisions, change of attitude towards themselves and others, recognition for themselves and others, self-discipline, moral and ethics, and self-value that is acceptable to society. For the community, participants of group study activities can be useful to the community after they have opportunities to develop themselves in various ways and change their behaviors to be desirable for society according to the social norm. They can then see value of themselves and make themselves useful for the community and as a result live happily in society.

Therefore, it can be said that organizing group study activities is one way that can prevent and reduce bullying behaviors among students because students are trained in the correct way with creative teaching, good role models, and above all, students are taught about the religion in order to train them to have good disciplines. Projects should be specially organized for students. Furthermore, the afore-mentioned ways of solving bullying behavior problems emphasize the process of socialization of the mind, emotion, intelligence, and soul in the Islamic way that is used as the main principle in solving the problem of bullying behaviors among students.

The results of the study are useful as they can be used as one way of solving, preventing, and reducing the problem of bullying behaviors among students. School administrators and teachers must realize and give importance to utilizing group study activities in the regular learning and teaching process or in the extra-curriculum activities. This is because the group study activity or "Hallakah" is the way that is part of the Muslim Life in every society and occupation and that is used as the main activity that should be promoted and supported. Schools can use a risk bullying behavior screening form to screen students before organizing group study activities for students who are found to have risk behaviors to participate so as to concretely prevent and manage the problem of bullying behaviors among students in the schools before such behaviors become more violent social problems. Therefore, it is one way of helping each other to find ways to timely solve the problems.

\section{Acknowledgements}

I would like to thank the Research Fund, Faculty of Liberal Arts, Prince of Songkla University for its financial support. 


\section{References}

Abu Ibanah. (n. d.). Hallakah in Islamic camp: Our camp are youth of the truth. Retrieved December 27, 2012, from http://www.fityatulhaq.net/forum/index.php?topic=158.0; wap2

Al-bulyan. (n. d.). Hallakah: Starting point of the changing for self and social. Retrieved December 27, 2012, from http://www.mistersor.exteen.com/20110413/entry-7

Amarin, T. (2000). The study of the nurturance of mathayom suksa IV students of Mahidol witthayanusorn school in changwat Nakhonpathom (Unpublished master's thesis). Srinakharinwirot University, Bangkok.

Astor, R., Meyer, H., Benbenishty, R., Marachi, R., \& Rosemond, M. (2005). School safety interventions: Best practices and programs. Children and Schools, 27(1), 17-32. http://dx.doi.org/10.1093/cs/27.1.17

Baron, R., \& Neuman, J. (1996). Workplace violence and workplace aggression: Evidence on their relative frequency and potential causes. Aggressive behavior, 22(3), 161-173. http://dx.doi.org/10.1002/(SICI)1098-2337(1996)22:3<161::AID-AB1>3.0.CO;2-Q

Bennet, M. E. (1963). Guidance and Counseling in Group. New York: McGraw Hill.

Birnbaum, M. L., \& Wayne, J. (2000). Group work in foundation generalist education: The necessity for curriculum change. Journal of Social Work Education, 36(2), 347-348.

Button, L. (1974). Development group work with adolescents. London: University of London Press.

Chaipan, K. (2006). Group process. Bangkok: Odean store.

Chatsupakul, K. (2003). Group activities in schools (5th ed.).Bangkok: Pattanasuksa.

Coloroso, B. (2004). The bully, the bullied, and the bystander: From pre-school to high school: How parents and teachers can help break the cycle of violence. New York: Harper Collins.

Deighton, L. C. (1971). Small group instruction: The encyclopedia of education. New York: The MacMillan Company and Free Press.

Farrington, D. (1993). Understanding and preventing bullying. In M. Tonry \& N. Morris (Eds.), Crime and Justice. Chicago: University of Chicago Press.

Kemp, C. G. (1965). Perspectives on the group process: A foundation for counseling with group (2nd ed.). Boston: Goughton Miffin.

Khemmanee, T. (2002). Relation group for working and teaching. Bangkok: Nichin Advertising Group.

Laeheem, K., \& Baka, D. (2009). Risk factors related to youths' violence behaviors in the three southern border provinces of Thailand. Songklanakarin Journal of Social Sciences and Humanities, 15(6), 897-911.

Laeheem, K., \& Baka, D. (2011). The risk factors are related to Thai Muslim youth's aggressive behavior in the three southern border provinces of Thailand. NIDA Development Journal, 51(3), 59-90.

Laeheem, K., \& Baka, D. (2012). A study of youth's violent behavior in the three southern border provinces of Thailand. NIDA Development Journal, 52(1), 159-187.

Laeheem, K., \& Sungkharat, U. (2012). Development of screening inventory for students at risk of exposure to bullying behavior in Islamic private schools, Songkhla province. Kasetsart Journal: Social Sciences, 33(2), 175-187.

Laeheem, K., Kuning, M., \& McNeil, N. (2009). Bullying: Risk factors becoming 'Bullies'. Asian Social Science, 5(5), 50-57.

Lhamlert, S. (2009). A study of aggressive behavior and self-controlled program development to reduce aggressive Behavior of female juveniles (Unpublished master's thesis). Srinakharinwirot University, Bangkok.

Marano, H. E. (1995). Big bad bully. Psychology Today, 28(5), 50-82.

Ohlsen, M. M. (1970). Group counseling. New York: Holt Rinegart and Winston.

Patterson, C. H. (2000). The counseling. CA: Brooks Cole Wadworth.

Pumpong, K. (2003). The using of group work activities in developing students' responsibilities among the Mathayumsuksa 2 students of Phetchaburi welfare school, Phetchaburi province (Unpublished master's thesis). Silapakorn University, Pethchaburi.

Ritnetikul, C. (2009). The effect of group activities on attitude toward value of virginity of female students 
(Unpublished master's thesis). Srinakharinwirot University, Bangkok.

Shaw, M. E. (1971). Group dynamic: The psychology of small group behavior (3rd ed.). New York: McGraw-Hill.

Sririchan, J. (2010). The effects of group activities on the development of self-regulation dimension of emotional quatient of prathom sueksa five students at Khlong Kum school, Bueng Kum district, Bangkok metropolis (Unpublished master's thesis). Ramkumhaeng University, Bangkok.

Sukchan, C. (1999). A study of the cause of juvenile delinquency in Bangkok (Unpublished master's thesis). Kasetsart University, Bangkok.

Traxler, A. E., \& North, R. D. (1966). Techniques of guidance. New York: Harper and Row.

Trotzer, J. P. (1977). The counsellor and the group: Integrating theory training and practice. Monterey: Brooks Cole Publishing.

Wattanapong, P. (2005). The effects of group dynamic on emotion intelligence of students in Matayomsuksa I at Rattanathibate school (Unpublished master's thesis). Srinakharinwirot University, Bangkok.

\section{Copyrights}

Copyright for this article is retained by the author(s), with first publication rights granted to the journal.

This is an open-access article distributed under the terms and conditions of the Creative Commons Attribution license (http://creativecommons.org/licenses/by/3.0/). 